\title{
Studying the Biology of Carpoglyphus lactis (L.) Reared on Dried Apricots and Its Control Using Plant Oil Extracts
}

\author{
Anar A. Bakr ${ }^{1}$, Hussien A. Rezk ${ }^{1}$, Madiha M. Abd El-Hamid ${ }^{1}$ and Sohair I. Osman ${ }^{1}$
}

\begin{abstract}
Carpoglyphus lactis(L.) has been documented as one of the most important pest contaminants of dried fruits during storage. Dried apricots are especially sensitive to the mite infestation, although data concerning bionomics and control of the mite on this subject is rare. In this study, the biological aspects of C.lactis fed on dried apricots were examined under laboratory conditions at $25 \pm 2^{\circ} \mathrm{C}$ and $85 \pm 5 \% \mathrm{RH}$ in complete darkness. Eggs required an average of $\mathbf{1 5 . 2}$ and 12.2 days to develop into adult females and males, respectively. The oviposition period averaged 10.2 days during which females deposited an average of 31.8 eggs with a daily rate of 3.18 eggs per female. Mean life span of females was longer than that of males being 29.33 and 22.0 days, respectively. The hatch rate was $78.83 \%$ and the female to male ratio was $1: 0.87$. The deutonymph (hypopus) stage was not found in the entire $C$.lactis life cycle. On the other hand, the acaricidal activity of the three plant oils extracts, cinnamon, chrysanthemum, and eucalyptus oils against $C$.lactis adults was bio-assayed after a $\mathbf{2 4 h}$ period via direct contact application. As measured by $\mathrm{LC}_{50}$ values, the most toxic oil was cinnamon $\left(\mathrm{LC}_{50}=5.6 \mathrm{ppm}\right)$ followed by chrysanthemum $\left(\mathrm{LC}_{50}=13.9 \mathrm{ppm}\right)$, and eucalyptus $\left(\mathrm{LC}_{50}=\right.$ 89.2ppm).
\end{abstract}

Key words: Bionomics, C.lactis, Control, Dried apricots, Plant oil extracts.

\section{INTRODUCTION}

Investigation of biological contaminants of stored dried fruits revealed their infestation with several arthropod pests. One of the most prominent pests is the dried fruit mite, Carpoglyphus lactis (L.) (Acaridida :Carpoglyphidae) (Çobanoğlu, 2009; Hubert et al., 2011). This mite mainly infests stored commodities rich in sugar and acids, especially acetic, lactic, and succinic acids which are produced via bacterial activity. Dairy products, honey, jam, rotten fruits, flour, cured ham, wine as well as dry fruits have been documented as the most favorable media for $C$. lactis infestation (Chemielewski, 1971; Arnau and Guerrero, 1994; Marin et al., 2009). In a screening survey carried out in Alexandria, Egypt, C. lactis was the most frequent and abundant mite species associated with dried apricot and fig with averages of 53.7 and 13.4 mites/g, respectively, recorded in August (Abd El-Razek, 2017). C. lactis is pestilential to many stored products, particularly under moist and warm climates as it contributes to their physical damage (Zhan et al, 2017) and leads to changes in their chemical composition (Marin et al., 2009). It causes allergic reaction in humans as well (Mullen and Oconnor, 2002).

Identification of biological aspects of a pest species is considered a substantial step for understanding the population dynamics of the mite which in turn leads to planning a successful management strategy. Recent storage pests research is focused on the establishment of new pesticides to substitute the prohibited and nonfunctional ones in stored product protection (Coldwell, 2020; Collins, 2006). Plant-derived products are known as potential sources for storage mite pest management with little or no detrimental impact on the human health and environment (Sung et al., 2006; Bakr, 2018). Therefore, this study was carried out to obtain more information on the bionomics of the dried fruit mite, $C$. lactis reared on dried apricots. In addition, the toxic effect of some plant oil extracts on C. lactis adults was evaluated in comparison to that of the synthetic acaricide, pirimiphos-methyl.

\section{MATERIALS AND METHODS}

\section{Biological studies:}

\section{Mite rearing}

Specimens of $C$. lactis were isolated from infested dried fruit samples obtained from local markets in Alexandria, Egypt. The mite colonies were reared in glass jars containing dried apricots. The stock jars were covered and kept at $25 \pm 2{ }^{\circ} \mathrm{C}$ and $80 \pm 5 \% \mathrm{RH}$ in complete darkness.

\section{Biological aspects}

Twenty freshly deposited eggs were singly transferred to small glass rearing cells $(1 \mathrm{~cm}$ diameter $\mathrm{X}$ $0.8 \mathrm{~cm}$ height) containing $1 \mathrm{mg}$ of dried apricots. The cells were then covered by a nylon mesh and maintained at the optimum rearing conditions described earlier. The developmental times of C.lactis stages were observed daily until maturity (Ibrahim, 2006; Bakr, 2018).

In a separate experiment, newly moulted adult females $(n=20)$ were separately transferred with young males to small rearing cells supplied with diet. The number of eggs deposited by each female was 
Table 1 . Tested essential oils and acaricide against the dried fruit mite $C$. lactis

\begin{tabular}{|c|c|c|}
\hline Tested compound & Major components & $\begin{array}{c}\text { Tested } \\
\text { concentration } \\
(\mathbf{p p m})\end{array}$ \\
\hline $\begin{array}{l}\text { Cinnamon Bark oil } \\
\text { (Cinnamomum zeylanicum) }\end{array}$ & $\begin{array}{l}\text { (E).cinnamaldehyde }(71.5 \%) \text {, Linalool }(7.0 \%) \text {, B- } \\
\text { caryophyllene }(6.4 \%) \text {,eucalyptol }(5.4 \%) \text {, eugenol } \\
(4.6 \%) \text { (Behahani et al., 2020) }\end{array}$ & $1-150$ \\
\hline $\begin{array}{l}\text { Chrysanthemum Leaf oil } \\
\text { (Chrysanthemum trifurcatum) }\end{array}$ & $\begin{array}{l}\text { Limonene } \quad(26.8), \quad \text { T-terpinene(19.6\%), } \quad \dot{\alpha}- \\
\text { pinene(9.7\%), } \dot{\alpha} \text {-terpenyl acetate }(7.2 \%) \text { (Sassi et al., } \\
2014)\end{array}$ & $4-150$ \\
\hline $\begin{array}{l}\text { Eucaluptus leaf oil } \\
\text { (Eucalypyus globulus) }\end{array}$ & $\begin{array}{l}1.8 \text { cineole (eucalyptol) }(44.3 \%) \text {, camphene (23.1), B- } \\
\text { pinene (12.7), d } \text {-pinene (9.5), Globulol (7.3), } \\
\text { Limonene (5.1\%) (Boukhatem et al., 2014). }\end{array}$ & $10-1000$ \\
\hline Pirimiphos - methyl & & $1-100$ \\
\hline
\end{tabular}

monitored and the eggs removed daily. Nourishment was provided when needed. The fecundity, longevity, hatchability, and sex ratio were recorded by taking observation every $24 \mathrm{~h}$.

\section{Bioassay studies:}

Three commercial plant oil extracts (cinnamon, chrysanthemum, and eucalyptus oils) were compared with a synthetic acaricide (pirimiphos-methyl) in the present study. Five concentrations from each compound were prepared (Table 1).

Filter paper discs $(1.5 \mathrm{~cm}$ diameter) were immersed for $10 \mathrm{sec}$ in oil solutions or in acetone as a control. The discs were allowed to dry for $10 \mathrm{~min}$ at room temperature. Each disc was placed at the bottom of a glass microcell $(1.5 \mathrm{~cm}$ diameter $X 2 \mathrm{~cm}$ height). Ten mixed adults of $C$. lactis were placed in each microcell using a fine needle then covered. The microcells were held at $25 \pm 2{ }^{\circ} \mathrm{C}$ and $80 \pm 5 \% \mathrm{RH}$ in the dark until mortality assessment. Mite mortalities were recorded $24 \mathrm{~h}$ post treatment and mites were regarded as dead if appendages did not move. Each treatment was represented by three replicates. Mortality data was corrected using Abbott's formula (Abbott, 1925) then subjected to probit analysis (Finney, 1971) to calculate the $\mathrm{LC}_{50}$ and their confidence limits.

\section{RESULTS AND DISCUSSION}

\section{Mite bionomics}

Both sexes of $C$. lactis reared on dried apricots at $25 \pm 2{ }^{\circ} \mathrm{C}$ and $80 \pm 5 \% \mathrm{RH}$ passed through egg, larva protonymph, and tritonumph stages before reaching adulthood (Table 2). Our observations confirmed that reproduction in $C$. lactis appears to be mostly sexual where mating happens one or two days after adult emerges. Eggs are laid by females one at a time in a scattered manner. They are globular and whitish in colour. Incubation period lasted $4.2 \pm 0.7 \& 3.0 \pm 0.8$ days for females and males, respectively. Concerning the total life cycle duration, it averaged $15.2 \pm 1.2$ days in females while being shorter in males (12.2 \pm 1.4 days). It is of interest to note that males developed earlier than females for each life stage (Table 2).

Comparison of our results with biological data obtained from previous studies shows that the developmental time of $C$. lactis varies according to temperature, relative humidity, and kind of food (Okamoto, 1986; Chmielewski, 1999). Okamoto (1986) observed that the life cycle of $C$. lactis averaged from 6.7 to 36.2 days in females and from 6.8 to 39.0 days in males at temperature ranging between 10 to $35^{\circ} \mathrm{C}$ and 90-100\% RH. Furthermore, our results demonstrate that the deutonymphal stage (hypopus) was not observed in the life cycle of $C$. lactis reared as described above. Our results are in harmony with Okamoto (1986) who reported that hypopus was not found in the entire $C$. lactis life cycle when reared on a mixture of sugar and dried yeast $(1: 1)$ at $25 \pm 2{ }^{\circ} \mathrm{C}$ and $85 \pm 5 \% \mathrm{RH}$. On the other hand, Chmielewski (1999) noticed that the deutonymph stage was not observed when $C$. lactis was fed on honey, but it was frequently present when the mite was fed on baker's yeast and pollen at $20^{\circ} \mathrm{C}$ and $85 \%$ RH. In addition, our results showed that $C$. lactis females fed on dried apricots deposited an average of $31.8 \pm 0.7$ eggs with a daily rate of $3.18 \pm 0.4$ eggs during the oviposition period which averaged 10.2 \pm 1.1 days. The average hatch rate was $78.83 \%$ and the female to male ratio was 1:0.87. Apparently, adult longevity was longer for females $(14.2 \pm 1.31$ days) than for males (9.83 \pm 0.9 days) (Table 3$)$. 
Table 2. Duration in days (Mean $\pm \mathrm{SE}$ ) of the immature stage of $C$. lactis reared on dried apricots at $25 \pm 2^{\circ} \mathrm{C}$ and $85 \pm 5 \% \mathrm{RH}$ in complete dark

\begin{tabular}{lcc}
\hline Stage & Female & Male \\
\hline Egg & $4.2 \pm 0.7$ & $3.0 \pm 0.8$ \\
Larva & $4.3 \pm 0.4$ & $3.3 \pm 0.6$ \\
Protonymph & $3.3 \pm 0.4$ & $3.2 \pm 0.4$ \\
Tritonymph & $3.5 \pm 0.5$ & $2.7 \pm 0.4$ \\
Life cycle & $15.2 \pm 1.2$ & $12.2 \pm 1.4$ \\
\hline
\end{tabular}

Table 3. Some biological aspects (Mean $\pm \mathrm{SE}$ ) of $C$. lactis adults reared on dried apricots at $25 \pm 2^{0} \mathrm{C}$ and $85 \pm 5 \%$ RH in complete dark

\begin{tabular}{|c|c|c|}
\hline Parameter & Female & Male \\
\hline Preovi. & $2.3 \pm 0.8$ & -------- \\
\hline Ovip. & $10.2 \pm 1.1$ & --------- \\
\hline Postovi. & $1.7 \pm 0.5$ & -------- \\
\hline Longevity & $14.2 \pm 1.3$ & $9.8 \pm 0.9$ \\
\hline Life span & $29.3 \pm 1.8$ & $22.0 \pm 1.1$ \\
\hline Fecundity & $31.8 \pm 0.7$ & --------- \\
\hline Daily rate & $3.2 \pm 0.4$ & --------- \\
\hline $\begin{array}{l}\text { Hatchability \% } \\
\text { Sex ratio }(\$ / \delta)\end{array}$ & & \\
\hline
\end{tabular}

Bionomics of $C$. lactis reared on wheat at $25 \pm 2{ }^{\circ} \mathrm{C}$ and $65 \pm 5 \% \mathrm{RH}$ were investigated by Ibrahim (2006) who reported that the oviposition period lasted 12.1 days during which females deposited an average of 55.9 eggs with a daily rate of 4.6 eggs/female. Also, she recorded that males lived shorter than females where females lived around 15.4 days and males around 6.2 days. The variation in results may be due to an array of factors including differences in food, strains, humidity, or the inherent variability of the species (Cunnington, 1985). In addition, Ibrahim (2006) studied the effect of photoperiod on the bionomics of $C$. lactis and it was found that the life cycle duration increased with increasing hours of light in both males and females. However, female fecundity, longevity, as well as mean daily deposited eggs decreased as the photoperiod increased.

\section{Acaricidal activity of essential oils}

The acaricidal activities of essential oils extracted from plants against $C$. lactis adults were bio-assayed by impregnated filter paper disc application and compared with the standard pirimiphos-methyl as a synthetic acaricide (Table 4).

Based on the 24-h $\mathrm{LC}_{50}$ values, cinnamon bark oil was the most toxic against $C$. lactis adults $\left(\mathrm{LC}_{50}=5.6\right.$ $\mathrm{ppm})$, its toxicity close to that of pirimiphos-methyl $\left(\mathrm{LC}_{50}=4.6\right)$, followed by chrysanthemum leaf oil $\left(\mathrm{LC}_{50}\right.$ $=13.9 \mathrm{ppm})$ and eucalyptus leaf oil $\left(\mathrm{LC}_{50}=89.2 \mathrm{ppm}\right)$ (Table 4).
Direct contact bioassay confirmed that the oil extracted from $C$. zeylanicum bark had a great acaricidal effect on $C$. lactis adults. This is probably due to the action of its major component, (E)-cinnamaldehyde, which constitutes more than $70 \%$ of cinnamon bark oil components (Behbahni et al., 2020). Similarly, De Assis et al., (2011) revealed that $C$. zeylanicum oil has a potent acaricidal activity against the stored product mites, Tyrophagus putrescentiae and Suidasia pontifica. It was recorded in other investigations done by Kim et al., (2004) and Kim et al., (2008) that (E)cinnamaldehyde caused death related to uncoordinated behavior response in Dermatophagoides farine, $D$. pteronyssinus, and $T$. putrescentiae. Regarding the acaricidal activity of chrysanthemum leaf oil, our results are consistent with the observations of Haouas et al., (2008) who reported that $C$. trifurcatum leaf oil extract caused deterrence and toxicity to the adult confused flour beetle, Tribolium confusum through both ingestion and topical applications. Earlier studies have revealed that essential oil toxicities are generally corresponding to their major constituents (Singh et al., 2003; Aslan et al., 2004) which suggest that the activities of oils shown in this study are probably associated with the main constituents listed in Table (1). Essential oils with their complex chemical composition are more efficient than isolated components as the various components of the oils may have interacted in a synergistic manner increasing and accelerating the toxic effects (Miresmailli et al., 2006; Singh et al., 2009). 
Table 4 . Toxicity of plants essential oils and pirimiphos-methyl towards $C$. lactis via direct contact bioassay after 24 h exposure

\begin{tabular}{ccccc}
\hline Treatment & Slope \pm SE & $\begin{array}{c}\text { LC50 } \\
(\mathbf{p p m})\end{array}$ & $\begin{array}{c}\text { Confidence } \\
\text { limits 95\% }\end{array}$ & RT* $^{*}$ \\
\hline Pirimiphos-methyl & $0.86 \pm 0.01$ & 4.6 & $3.1-6.5$ & 1.0 \\
Cinnamon bark oil & $0.80 \pm 0.01$ & 5.6 & $3.8-8.1$ & 0.80 \\
Chrysanthemum leaf oil & $1.01 \pm 0.01$ & 13.9 & $11.8-30.3$ & 0.32 \\
Eucalyptus leaf oil & $0.98 \pm 0.01$ & 89.2 & $66.5-120.7$ & 0.05 \\
\hline
\end{tabular}

*relative toxicity $=\mathrm{LC}_{50}$ value of pirimiphos-methyl/LC $\mathrm{L}_{50}$ value of each compound

As a conclusion, under suitable developmental conditions, $C$. lactis can be a serious contaminant to stored dried fruits as their number can grow rapidly which in turn leads to reduction in quality and marketability of dried fruit commodities. Essential oils tested in this study, in particular cinnamon and chrysanthemum oils, hold promising potential for usage as a possible alternative to synthetic products and can be integrated in sustainable stored product pest control strategies. However, further studies should be done on the impact of these compounds on the organoleptic characteristics of dried fruits treated with such compounds.

\section{REFERENCES}

Abbott, W.S. 1925. A method of computing the effectiveness of an insecticide. J.of Economic Entomology, 18:265267.

Abd El- Razek, S.I.O. 2017. Studies on some stored product mites .Msc. Thesis ,Faculty of Agriculture ,Alexandria university

Arnau, J. and L. Guerrero . 1994. Physical methods of controlling mites in dry cured ham. Fleischwirtschaft, 74: 1311-1313.

Aslan, İ.,H. Özbek, Ö. Çalmaşur and F. Şahin. 2004. Toxicity of essential oil vapours to two greenhouse pests, Tetranychus urticae Koch and Bemisia tabaci Genn. Industrial Crops and Products, 19: 167-173.

Bakr, A.A .2018. Feeding deterrent effects of legume flours against two storage mites, Tyrophagus putrescentiae (Schrank) and Suidasia medanensis Oudemans (Acari: Acaridida). Systematic and Applied Acarology ,23:380-386.

Behbahani, B.A., F. Falah, F.L. Arab, M. Vasiee and F.T. Yazdi. 2020. Chemical Composition and Antioxidant, Antimicrobial, and Antiproliferative Activities of Cinnamomum zeylanicum Bark Essential Oil. EvidenceBased Complementary and Alternative Medicine, 1-8.

Boukhatem, M. N., F. M. Amine, A. Kameli, F. Saidi, K. Walid and S. B. Mohamed. 2014. Quality assessment of the essential oil from Eucalyptus globulus Labill of Blida (Algeria) origin. International Letters of Chemistry, Physics and Astronomy, 36: 303-315.
Chmielewski, W. 1999. results of biological study on feeding of dried fruit mite carphglyphus lactis (L.) (Acarina: Carpoglyphidae). Nauk, 22:173-179.

Chmielewski, W. 1971. Morphology, biology and ecology of Carpoglyphus lactis (L., 1758) (Glycyphagidae, Acarina). Prace Nauk. Inst. Ochr. Roslin, 13:63-66.

Çobanoğlu,S. 2009. Mite population density analysis of stored dried apricots in Turkey. International J. of Acarology, 35: 67-75.

Coldwell,J.M. 2020. Alternatives to conventional pesticides .Food technology magazine,74:5.

Collins, D.A. 2006.A review of alternatives to organophosphorus compounds for the control of storage mites .J.of stored products research, 42:395-426.

Cunnington, A. M. 1985. Factors affecting oviposition and fecundity in the grain mite Acarus siro L. (Acarina:Acaridae), especially temperature and relative humidity. Experimental and Applied Acarology, 1: 327344.

De Assis, C. P. O., M. G. C. Gondim, H. A. A. de Siqueira and C. A. G. da Câmara. 2011. Toxicity of essential oils from plants towards Tyrophagus putrescentiae (Schrank) and Suidasia pontifica Oudemans (Acari: Astigmata). J. of Stored Products Research, 47: 311-315.

Finney, D.J. 1971. Probit Analysis. 3rd Edition, Cambridge University Press, Cambridge, xv $+333 p p$.

Haouas, D., M. Ben Halima-Kamel, F. Skhiri-Harzallah and M.H. Ben Hamouda.2008. Chrysanthemum Methanolic Extracts as Potential Insecticidal Sources on Tribolium confusum Du Val (Coleoptera: Tenebrionidae). Journal of Agronomy, 7: 93-97.

Hubert, J., V. Stejskal, T. Erban and M. Nesvorna. 2011. Emerging risk of infestation and contamination of dried fruits by mites in the Czech Republic. Food Additives and Contaminants. Part A, 28:1129-1135.

Ibrahim, W. 2006. Effect Of Photoperiod On The Development And Fecundity Of Carpoglyphus lactis L. ( Acari: Carpoglyphidae ). The Egyptian J. of Hospital Medicine, 23: 212-218.

Kim, H.-K., J.R. Kim and Y.-J. Ahn. 2004. Acaricidal activity of cinnamaldehyde and its congeners against Tyrophagus putrescentiae (Acari: Acaridae). J. of Stored Products Research, 40:55-63. 
Kim, H.K., Y.K. Yun and Y.J. Ahn. 2008. Fumigant toxicity of cassia bark and cassia and cinnamon oil compounds to Dermatophagoides farinae and Dermatophagoides pteronyssinus (Acari: Pyroglyphidae). Experimental and Applied Acarology, 44:1-9.

Marín, J., R. Ocete, M. Pedroza, A. Zalacain, C. de Miguel, M. A. López and M. R. Salinas. 2009. Influence of the mite Carpoglyphus lactis (L) on the aroma of pale and dry wines aged under flor yeasts. J. of Food Composition and Analysis, 22: 745-750.

Miresmailli, S., R. Bradbury and M.B. Isman. 2006. Comparative toxicity of Rosmarinus officinalis L. essential oil and blends of its major constituents against Tetranychus urticae Koch (Acari: Tetranychidae) on two different host plants. Pest Management Science, 62:366371.

Mullen, G. R. and B. M. Oconnor. 2002. Mites (Acari). In: G. Mullen and L. Durden [eds.], Medical and Veterinary Entomology. Academic, San Diego, CA. 449-516 pp.

Okamoto, M. 1986. The effects of various temperatures on the life cycle of Carpoglyphus lactis. Medical Entomology and Zoology, 37: 221-227.
Sassi, A.B., F.H. Skhiri, I .Chraief, N. Bourgougnon, M. Hammami and M. Aouni. 2014. Essential oils and crude extracts from Chrysanthemum trifurcatum leaves, stems and roots: chemical composition and antibacterial activity. J.of Oleo Science, 63: 607-617.

Singh, G., O. P. Singh, M. P. de Lampasona and A. N. Cesar Catalan. 2003. Studies on essential oils, Part 35: Chemical and biocidal investigation on Tagetes erecta leaf volatile oil. Flavor and Fragrance Journal, 18: 62-65.

Singh, R., O. Koul, P. J. Rup and J. Jindal. 2009. Toxicity of some essential oil constituents and their binary mixtures against Chilo partellus (Lepidoptera: Pyralidae). International J. of Tropical Insect Science, 29:93-101.

Sung, B.K., J.H. Lim and H.S. Lee. 2006. Food protective and color alteration effects of acaricidal aldehydes on Tyrophagus putrescentiae (Schrank). J.of Food Protection, 69:1728-31.

Zhan, X.D., C.P. Li and Q. Chen. 2017. Carpoglyphus lactis (Carpoglyphidae) infestation in the stored medicinal Fructus Jujubae. Nutricion Hospitalaria, 34:171-174.

\title{
الملخص العربي
}

\section{دراسة بيولوجيا حلم الفواكه المجففة Carpoglyphus lactis(L.) المربى على المشم المجفف ومكافحته باستخدام مستخلصات الزيوت النباتية}

\author{
أنار عبدالله بكر ,حسين عبدالله رزق ,مديحة محمد عبد الحميد وسهير ابراهيم عثمان
}

/انثى • متوسط فترة حياة الإناث كانت أطول من الذكور

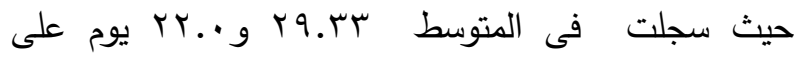

التوالى .معدل فقس البيض سجل فى المتوسط rی.A

\%ونسبة الإناث /الأكور سجلت / / . NV. على الترتيب

طور الحورية الثانى لم يلاحظ خلال دورة حياة هذا الحلم.

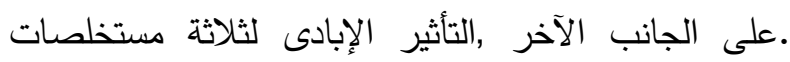

زيوت نباتية تسىى ,زيت القرفة ,الإقحوان والكافور ضد

الأفراد البالغة لحلم C.lactis تم تقييم السمية لها بعد تطبيقها

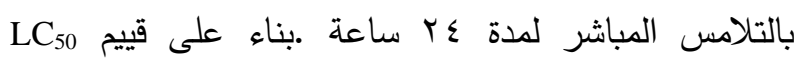

الزيت الأكثر سمية كان هو زيت القرفة ( LC

متبوعا بزيت الإقحوان (LC50=13.9ppm) ثم زيت الكافور

$\left(\mathrm{LC}_{50}=89.2 \mathrm{ppm}\right)$
حلم Carpoglyphus lactis(L.) تم توثيقه كأحد أهم

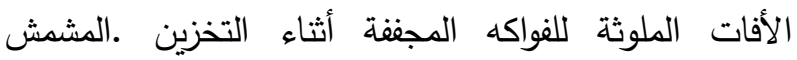
المجفف له حساسية خاصة للإصابة بهذا الحلم روبألرغم من ذلك المعلومات عن السمات البيولوجية وطرق المكافحة لحلم الفواكه المجفقة على هذه المادة تعتبر نادرة .فى هذه الدراسة تم دراسة السمات البيولوجية لحلم C.lactis المتغذى على, المشمش المجفف تحت الظروف المعملية عند حرارة

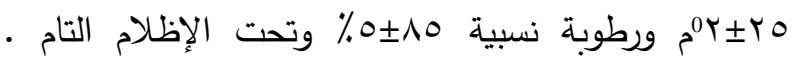

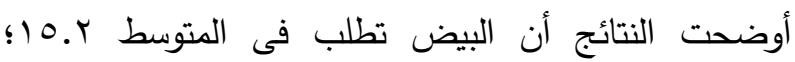
Y. Y. يوم ليتطور إلى إناث وذكور بالغة على التوالى .فترة وضع البيض كانت فى المتوسط r. . ايوم وضعت خلالها

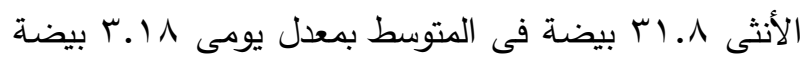

